\title{
Effect of strawberry vein banding virus and strawberry mottle virus co-infection on the growth and development of strawberry
}

\author{
Lingiao FAN ${ }^{1}$; Dan SONG ${ }^{1}$; Yingwei $\mathrm{KHOO}^{2}$; Mengmeng WU ${ }^{1}$; Tengfei XU ${ }^{1}$; XiaOli ZHAO ${ }^{1}$; HongQIng WANG W $^{1, *}$ \\ ${ }^{1}$ College of Horticulture, China Agricultural University, Beijing, 100193, China \\ 2 State Key Laboratory of Biology of Plant Diseases and Insect Pests, Institute of Plant Protection, Chinese Academy of Agricultural Sciences, Beijing, \\ 100193, China
}

Key words: Photosynthesis, Flowering and fruiting period, Antioxidants, Plant defense

\begin{abstract}
Strawberry mottle virus (SMoV) and strawberry vein banding virus (SVBV) cause diseases on strawberry plants, but the effect of coinfection of SMoV and SVBV on the growth, development, and defense system of strawberry (Fragaria $\times$ ananassa Duchesne) remains unknown. We investigated the effect of SMoV and SVBV coinfection on strawberry cultivar 'Benihope'. The results showed that stem diameter, leaf size, leaf number, relative chlorophyll content, total chlorophyll content, photosynthetic parameters, and stomatal aperture of SMoV and SVBV co-infected strawberry (VIS) plants were in a weaker level than uninfected control plants, indicating that viruses inhibited the growth and photosynthesis of strawberry plants. Furthermore, the initiation of flowering and fruiting stages of VIS plants were delayed by about three weeks compared with the controls, and the fruiting period was shortened, demonstrating that the reproduction of VIS plants was inhibited. Fruit quality was damaged in VIS plants due to a significant increase in fruit firmness and titratable acidity and decrease in total soluble solid content than control fruits. More dead cells and $\mathrm{H}_{2} \mathrm{O}_{2}$ accumulated along the veins of VIS leaves, and the content of abscisic acid and catalase activity significantly increased, whereas anthocyanin content was lower than that of control plants. The results demonstrate that SVBV and SMoV coinfection inhibits the growth and development of 'Benihope' strawberry plants, and the plants respond to viruses by regulating stomatal aperture, the accumulation of ABA and antioxidants. To our knowledge, this study contributes information to understand how both viruses impair the strawberry growth and development for the first time.
\end{abstract}

\section{Introduction}

China is the world's largest strawberry-producing country, and it produced nearly three million tonnes of fruit in 2018 (FAOSTAT, 2018). By contrast to in developed Western countries, Chinese strawberry (Fragaria $\times$ ananassa Duchesne) cultivation is mainly facilitated by complex climate conditions (Deng and Lei, 2005). A short-day strawberry cultivar that is planted at the end of August and that blooms and bears fruit in mid-October, is preferentially cultivated in China. The Japanese strawberry cultivar 'Benihope' is a typical short-day cultivar and is grown widely in Beijing due to its high-quality fruit. However, 'Benihope' plants are susceptible to diseases (Luo et al., 2019). Generally, strawberry is propagated vegetatively via runners, which explains how viruses can be transmitted

*Address correspondence to: Hongqing Wang, wanghq@cau.edu.cn Received: 24 February 2021; Accepted: 17 June 2021 from mother to daughter plants. Previous reports have described the detection, symptoms and vectors for strawberry viruses and virus-like diseases of strawberry (Tzanetakis, 2010; Dara, 2015; Wu et al., 2019). In China, strawberry vein banding virus (SVBV), strawberry mottle virus (SMoV), strawberry mild yellow edge virus (SMYEV), strawberry crinkle virus (SCV), strawberry necrotic shock virus (SNSV), cucumber mosaic virus (CMV), strawberry crinivirus 3 (SCrV-3), strawberry crinivirus 4 (SCrV-4) and strawberry-associated virus $1(\mathrm{SaV} 1)$ have been reported to infect strawberry. (Li and Yang, 2011; Chen et al., 2014; Li et al., 2014; Chen et al., 2018; Ding et al., 2019; He et al., 2021). Only SVBV and SMoV are considered here because they are the common viruses that infect strawberry in China.

SVBV belongs to the genus Caulimovirus within the family Caulimoviridae, and was first discovered on strawberries in the USA and described in 1955 (Frazier, 1955; Mráz et al., 1997; Petrzik et al., 1998). SVBV is transmitted to strawberry in a semi-persistent mode predominantly by the aphids Chaetosiphon fragaefolii, 
C. thomasi, and C. jacobi (Martin and Tzanetakis, 2006). To date, SVBV is restricted to Fragaria spp. Some modern cultivars, except 'Gaviota', 'Cuesta', 'Pacifica', and 'Selva', remain symptomless when they are infected with SVBV alone (Martin and Tzanetakis, 2006). Strawberry plants infected with different strains of SVBV show the yellowing of the main veins, leaf curling, vein banding, leaf necrosis, a reduction in fruit yield, and poor fruit quality (Mahmoudpour, 2003; Martin and Tzanetakis, 2006; Tzanetakis and Martin, 2013).

$\mathrm{SMoV}$ is considered to be the most common virus that infects strawberry (Tzanetakis and Martin, 2013; Thompson et al., 2017). SMoV was first described in 1940 and was characterized as a distinct virus in 1946, when it was isolated from 'mild yellow edge' as a result of different aphid transmission properties (Prentice and Harris, 1946). SMoV was recently assigned to the newly proposed subgenus "Stramovirus" within the genus Sadwavirus, family Secoviridae (Sanfacon et al., 2020). SMoV is transmitted in a semi-persistent manner by Chaetosiphon spp. and Aphis gossypii. It causes viral symptoms on F. vesca indicator plants, which range from barely discernible mild leaf mottling to severe stunting and distortion, and plant death, depending on the severity of the strains and other viruses present in the host plants. Severe strains of $\mathrm{SMoV}$ can reduce vigor and yield by up to $30 \%$ and a greater impact on yield is observed when SMoV coinfects strawberry with other viruses (Martin and Tzanetakis, 2006).

Host responses and virus-host interactions are popular topics of study in the field of plant virology. Host responses after virus infection and virus-host defense mechanisms in plants have been extensively reviewed. Following plant infection, viruses need to escape defenses initiated by the plant, and initiate a battery of different processes to complete their productive cycle (Maule et al., 2002). In response to infection, plants deploy antiviral immune responses, hypersensitive and necrotic resistance pathways, systemic necrosis, the salicylic acid pathway, and $\mathrm{R}$ genemediated responses (Mandadi and Scholthof, 2013). In recent years, the transcriptomic response of $F$. vesca following SVBV infection has been studied and suggests that SVBV affects the metabolism of plant pigments (anthocyanins and flavonoids), photosynthesis and plant-pathogen interactions (Chen et al., 2016). However, knowledge concerning the physiological responses of strawberry plants to viral infection is lacking, and a detailed description of the effect of viruses on the growth and development of strawberry has also not been reported. In this study, strawberry plants of the 'Benihope' cultivar coinfected by SVBV and SMoV were used as experimental material. We investigated strawberry plant growth and development, and determined physiological indices related to plant defense in response to these viruses.

\section{Materials and Methods}

\section{Plant material}

'Benihope' strawberry plants, from Donggang City of Liaoning Province, were tested for SMoV, SVBV, SMYEV, SCV, CMV and SNSV according to previous method (Fan et al., 2021). Only SMoV and SVBV were detected. Ten both SMoV and SVBV positive strawberry plants were used as mother plants to produce more viral plants. Virusfree 'Benihope' strawberry plants at the same seedling stage as viral plants were obtained from shoot tip culture for elimination virus and used as mock controls. Three biological replicates were analyzed for both viral plants and mock controls, with 15 plants per replicate. These plants were cultivated on the upper layer of the H-shaped cultivation rack of a greenhouse at the China Agricultural University in early September 2018. Sufficient sunlight was provided, and 60-mesh insect nets were hung after planting to prevent infestation by insects.

\section{Determination of physiological indices and fruit quality}

Plant stem diameter and plant height of SMoV and SVBV coinfected strawberry (VIS) plants and virus-free strawberry (control) plants were measured from the end of September, every two weeks. The percentage of stem diameter increase was calculated by (stem diameter 5 weeks - stem diameter 1 weeks $) /$ stem diameter 1 weeks $\times 100 \%$. Leaf number, petiole length, leaflet width, leaflet length, and leaflet area were recorded in early October. The number of flowering plants and fruit yield per plant were recorded weekly from midOctober to the end of February. Non-deformed fruits of the same maturity stage were measured using vernier calipers to determine the vertical and horizontal diameters of the fruits to the nearest $0.01 \mathrm{~mm}$. Fruit firmness was measured using an FHM-5 fruit hardometer (TAKEMURA, Japan). A handheld refractometer (ATC-32, Shanghai, China) was used to measure the content of fruit total soluble solids (TSS). The titratable acidity (TA) was measured using the acid-base titration method described by Berezin et al. (1995). The fruit shape index represents the ratio between the vertical and horizontal diameter of the fruits.

\section{Determination of photosynthetic indices}

The spectrophotometric method described by Lichtenthaler and Buschmann (2001) was used to determine the contents of chlorophyll a (Chla) and Chlb, carotene and total Chl in plant leaves at the reproductive stage. A total of 45 leaf punches (about $45 \mathrm{mg}$, three leaf punches per plant) per replicate were collected and extracted with $4.5 \mathrm{~mL} 95 \%$ ethanol. The relative Chl content of the core leaf, the first leaf from the core and the second leaf from the core of strawberry plants at the reproductive stage was determined using a SPAD-502Plus chlorophyll meter (Konica Minolta, Osaka, Japan). The photosynthetic parameters, including net photosynthesis rate $\left(\mathrm{P}_{\mathrm{N}}\right)$, stomatal conductance $\left(\mathrm{g}_{\mathrm{s}}\right)$, intercellular $\mathrm{CO}_{2}$ concentration $\left(\mathrm{c}_{\mathrm{i}}\right)$ and transpiration rate (E) were measured at 10:00 during the flowering phase using a portable photosynthesis system (LI-6400XT, LICOR, Lincoln, NE, USA). Total 15 fully developed leaves closest to the top in each replicate were determined at a leaf temperature of $20^{\circ} \mathrm{C} \pm 2{ }^{\circ} \mathrm{C}$, a relative humidity of $60 \%-65 \%$, an irradiance of $400 \mu \mathrm{mol} / \mathrm{m}^{2} \mathrm{~s}$, a $\mathrm{CO}_{2}$ concentration of $400 \mu \mathrm{mol} / \mathrm{mol}$ and a flow of $500 \mu \mathrm{mol} / \mathrm{s}$.

\section{Trypan blue staining}

Trypan blue staining was performed as described previously (Strober, 2015) with slight modification. Undamaged, second fully expanded leaves of the same age at the reproductive 
stage of strawberry plants were collected and immersed in $4 \%$ trypan blue staining solution, and then subjected to vacuum under a pressure of $0.9 \mathrm{~kg} / \mathrm{cm}^{2}$ for $6 \mathrm{~min}$. The staining solution was decanted after heating in a boiling water bath for $2 \mathrm{~min}$. Treated leaves were decolorized in hot $75 \%$ ethanol for 20-30 $\mathrm{min}$.

\section{Histochemical detection of ROS}

The accumulation of the ROS species hydrogen peroxide $\left(\mathrm{H}_{2} \mathrm{O}_{2}\right)$ and superoxide $\left(\mathrm{O}_{2}{ }^{-}\right)$was detected using the DAB and NBT staining methods, respectively. DAB staining solution was prepared as described by Daudi and O'Brien (2012). Undamaged, second fully expanded strawberry leaves at the same age and the same plant reproductive stage were immersed in the DAB staining solution, and vacuum infiltrated at a pressure of $0.9 \mathrm{~kg} / \mathrm{cm}^{2}$ for $6 \mathrm{~min}$ and were then shaken at $80-100 \mathrm{rpm}$ for $8-12 \mathrm{~h}$. The treated leaves were then destained in $75 \%$ hot ethanol (Daudi and O'Brien, 2012). A visible brown DAB-polymer was generated by the polymerization of $\mathrm{DAB}$ at the sites of $\mathrm{H}_{2} \mathrm{O}_{2}$ accumulation in the presence of endogenous peroxidase. For the in situ detection of $\mathrm{O}_{2}{ }^{-}$species, the procedure described by Jambunathan (2010) was followed. Undamaged, second fully expanded strawberry leaves at the reproductive stage of plants were completely immersed in $0.1 \%$ NBT staining solution containing $0.02 \mathrm{~mol} / \mathrm{L}$ of $10 \mathrm{mM}$ phosphate buffer $(\mathrm{pH} 7.0)$. The leaves were then vacuum infiltrated at a pressure of $0.9 \mathrm{~kg} / \mathrm{cm}^{2}$ for $6 \mathrm{~min}$. After staining, the treated leaves were cleared in $75 \%$ hot ethanol to remove the background green color. Visible blue spots were produced as a result of the reduction of NBT by $\mathrm{O}_{2}{ }^{-}$.

\section{Determination of antioxidants}

The second fully expanded leaves of strawberry plants at the reproductive stage were harvested to determine the concentration of antioxidants. The enzymatic activities of superoxide dismutase (SOD) and catalase (CAT) were measured following the methods described by Feng and Wei (2012). Extracting solvent (100\% methanol solution and 37\% $\mathrm{HCl}$ at the ratio of $99: 1 ; \mathrm{v} / \mathrm{v})$ was used to determine the anthocyanin content (Drumm and Mohr, 1978). The proline content was determined using a ninhydrin-based colorimetric assay (Ábrahám et al., 2010).

\section{Determination of abscisic acid $(A B A)$}

The ABA content of strawberry leaves at the reproductive stage was determined using an $\mathrm{ABA}$ enzyme-linked immunoassay kit according to the manufacturer's instructions (Jiangsu Enzyme Biotechnology Co., Ltd., Jiangsu). The mixed leaf sample of 15 strawberry plants $(0.5 \mathrm{~g})$ per replicate was extracted with $5 \mathrm{~mL}$ of $80 \%$ methanol as previously described (Luo et al., 2020).

\section{Statistical analysis}

The experiment consisted of a completely randomized design (CRD) with three replications. Microsoft Excel 2019 was used for data processing and plotting. The data were articulated as the mean \pm standard deviation $(\mathrm{SD})(\mathrm{N}=3$ replicates, 15 plants per replicate). One-way analysis of variance (ANOVA) and the SD were performed and calculated, respectively, using IBM SPSS Statistics 20.0 software at $P \leq 0.05$.

\section{Results}

VIS plants were from ten mother plants that were positive for SMoV and SVBV while negative for other four tested viruses by RT-PCR (Figs. 1A and 1B). For experimental strawberry plants, 44 samples including 22 VIS and 22 control plants were chosen randomly to test viruses by RT-PCR. The result showed that all VIS samples were positive for $\mathrm{SMoV}$ and SVBV (Figs. 1C and 1D), and all control samples were negative for tested viruses (Figs. $1 \mathrm{E}$ and $1 \mathrm{~F}$ ). The leaves of most VIS plants showed different degrees of distortion, chlorosis, and vein banding (Figs. 2A, 2B, and 2D). Some viral leaves were no obvious symptom (Fig. 2C).

From the vegetative growth stage (1-3 weeks) to the reproductive growth stage (4-6 weeks), the stem diameter of VIS plants was significantly lower than that of the control plants (Tab. 1). The increase in stem diameter of control and VIS plants was calculated from week 1 to week 5 and was larger for control plants $(18.40 \%)$ than for the VIS plants' (12.21\%). The height of VIS and control plants did not differ significantly (data not shown).

The leaf characteristics of control and VIS plants were measured, and the petiole length of VIS leaves was not significantly different from that of the control (Tab. 2). The leaflet width, length, area, and leaf number of VIS plants were also significantly lower in VIS plants than in control plants.

The relative chlorophyll content (RCC) of the core leaf, the first leaf outside the core and the second leaf outside the core was $6.88 \%, 6.34 \%$ and $9.75 \%$ significantly lower, respectively, than that in the corresponding control leaves (Fig. 3).

No significant differences in the Chla and carotene content and Chla/b ratio were observed between control and VIS plants, but the Chlb and total Chl contents of VIS plants were significantly lower than in control plants (Tab. 3).

The photosynthetic parameters $\left(\mathrm{P}_{\mathrm{N}}, \mathrm{g}_{\mathrm{s}}, \mathrm{E}, \mathrm{c}_{\mathrm{i}}\right)$ for VIS plants were lower than for control plants (Tab. 4) and values for $\mathrm{P}_{\mathrm{N}}, \mathrm{g}_{\mathrm{s}}, \mathrm{c}_{\mathrm{i}}$ and $\mathrm{E}$ for VIS plants were $12.31 \%$, $38.78 \%, 4.15 \%$ and $19.62 \%$ significantly lower, respectively, than those for control plants (Tab. 4).

Three fully developed leaves closest to the top (one leaf per plant) per replicate were chosen randomly and observed stomatal aperture of the lower leaf epidermis under the microscope at $400 \times$ magnification. The results showed that the stomatal aperture of all VIS leaves was smaller than control leaves (Fig. 4).

To establish the frequency of flowering and fruiting, October 17 was defined as the first day of the first week. The control plants began to flower on 10 October and showed a flowering frequency of $22.2 \%$ on October 17 (1 week) (Fig. 5A). By contrast, the VIS plants started to flower approximately three weeks later than the control plants, in early November. The peak flowering stage of control occurred on October 31 ( 3 weeks) but for the VIS plants, this was recorded on November 28 (7 weeks), which represented a delay of about four weeks. No significant difference in total flowering frequency was observed between control plants and VIS plants at eight weeks (Fig. 5A). The control fruits started to ripen in midNovember and yielded about $1.4 \mathrm{~g}$ per plant on November 21 (6 weeks), whereas the VIS fruits became ripe on about 


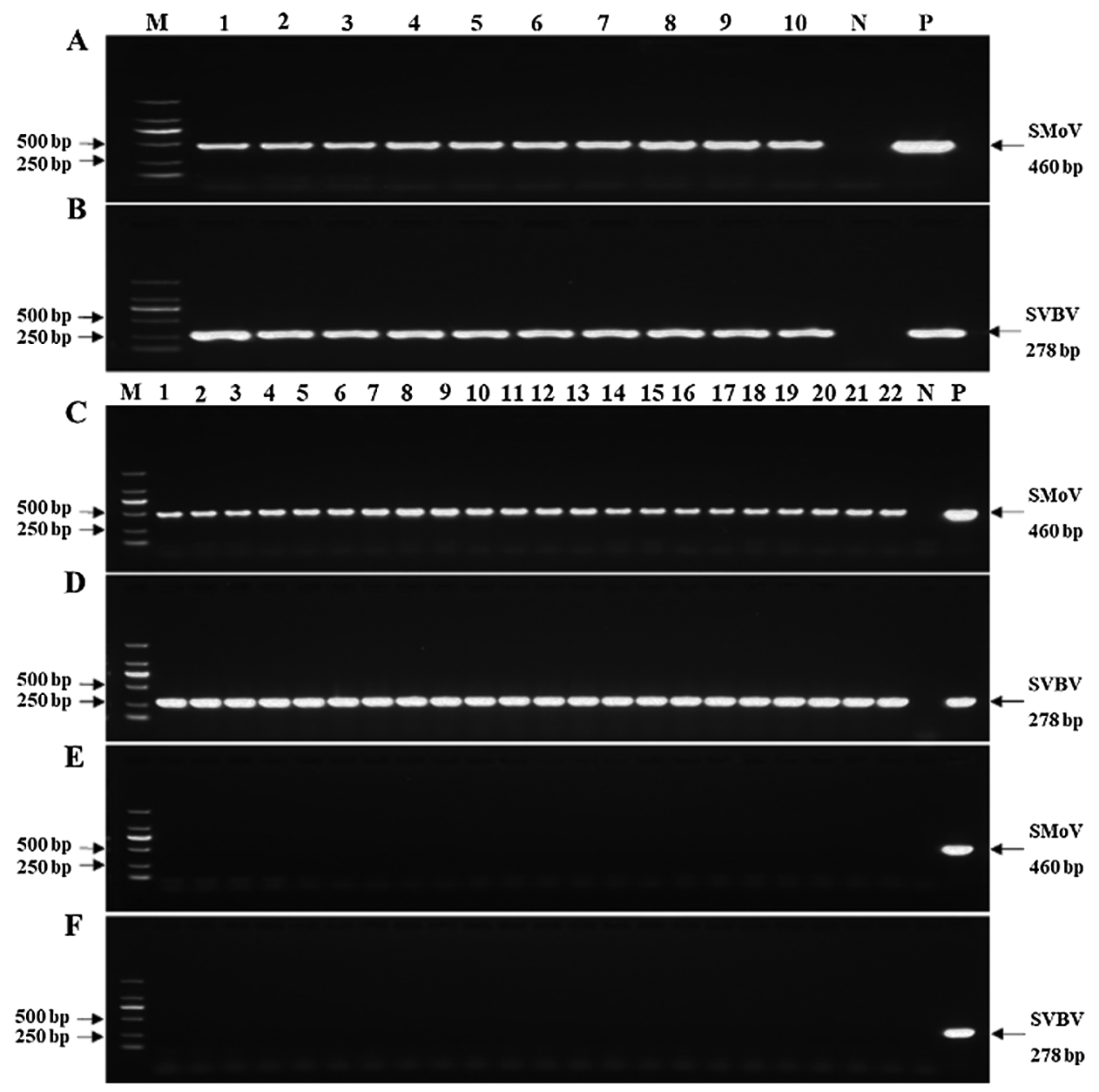

FIGURE 1. Investigation of strawberry mottle virus $(\mathrm{SMoV})$ and strawberry vein banding virus (SVBV) in strawberry plants by RT-PCR. (A-B) Ten mother plants were positive for both SMoV and SVBV. (C-D) 22 VIS samples chosen randomly were positive for both SMoV and SVBV. (E-F) 22 control samples chosen randomly were negative for both SMoV and SVBV. Abbreviations: $M$, DNA marker 2000; N, doubledistilled water as a negative control; $\mathrm{P}$, SVBV or $\mathrm{SMoV}$ plasmid as a positive control.

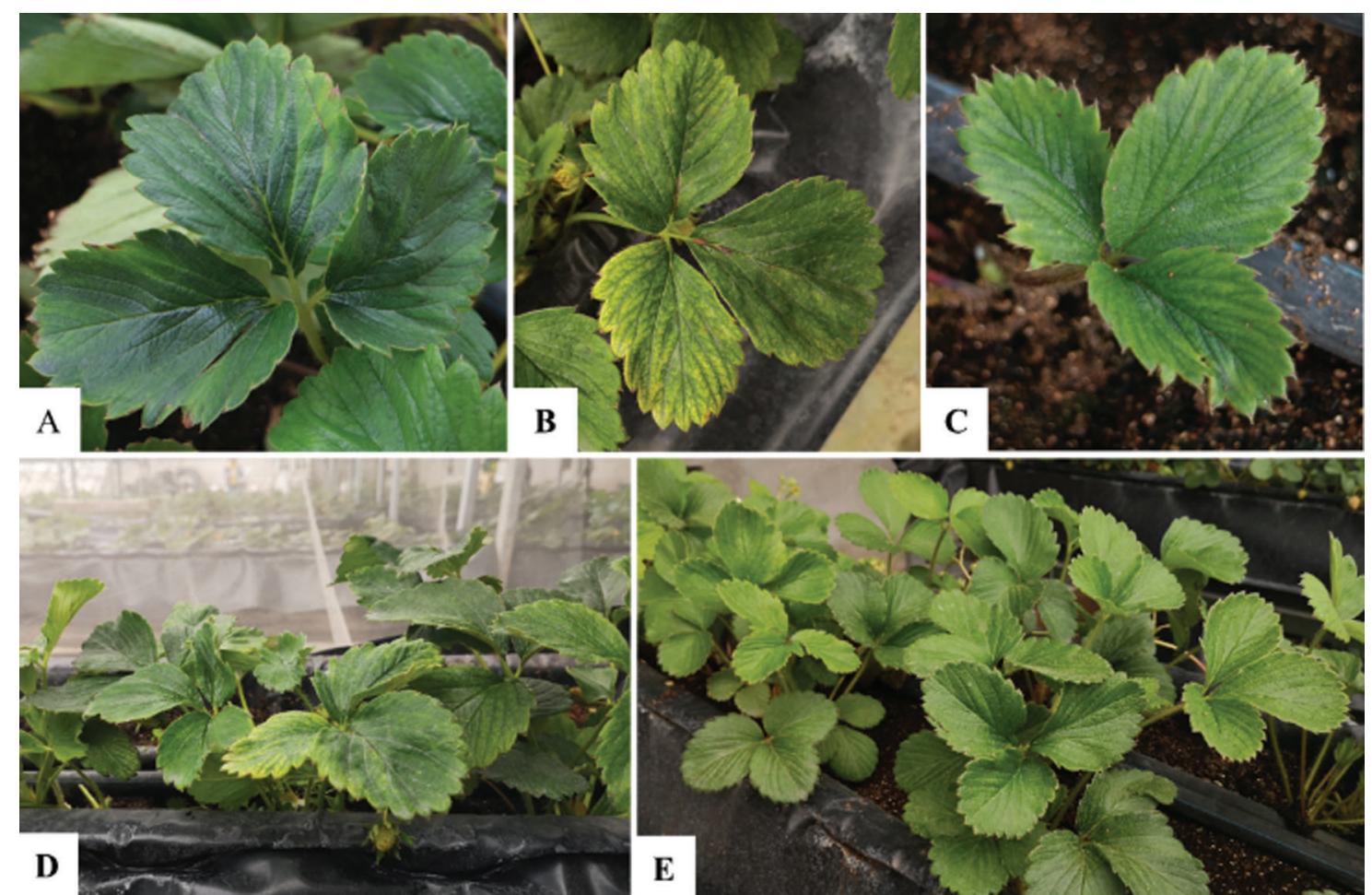

FIGURE 2. Field performance of 'Benihope' strawberry. (A-D) Strawberry plants co-infected by SMoV and SVBV. (E) Virus-free strawberry (control) plants. 
TABLE 1

The effect of strawberry vein banding virus (SVBV) and strawberry mottle virus (SMoV) on the stem diameter of 'Benihope' strawberry

\begin{tabular}{llllll}
\hline & 1 week $(\mathbf{m m})$ & 2 weeks $(\mathbf{m m})$ & 3 weeks $(\mathbf{m m})$ & 4 weeks $(\mathbf{m m})$ & 5 weeks $(\mathbf{m m})$ \\
\hline Control & $13.21 \pm 0.83$ & $14.24 \pm 0.66$ & $15.09 \pm 0.58$ & $15.61 \pm 0.63$ & $15.64 \pm 0.60$ \\
VIS & $11.22 \pm 1.17^{\star *}$ & $11.92 \pm 0.88^{\star *}$ & $12.28 \pm 1.03^{\star *}$ & $12.50 \pm 0.99^{* *}$ & $12.59 \pm 1.44^{\star *}$ \\
\hline
\end{tabular}

Note: ${ }^{* *}$ Significantly different to control values at $P<0.01$. Values are means $\pm \mathrm{SD},(\mathrm{N}=3$ replicates, 15 plants per replicate).

TABLE 2

The effect of SVBV and SMoV on leaf characteristics of 'Benihope' strawberry

\begin{tabular}{llllll}
\hline & Petiole length $(\mathbf{c m})$ & Leaflet width $(\mathbf{c m})$ & Leaflet length $(\mathbf{c m})$ & Leaflet area $\left(\mathrm{cm}^{2}\right)$ & Leaf number \\
\hline Control & $8.78 \pm 2.10$ & $5.24 \pm 0.43$ & $6.60 \pm 0.58$ & $23.69 \pm 3.03$ & $5.89 \pm 0.95$ \\
VIS & $8.84 \pm 1.87$ & $4.40 \pm 0.32^{* *}$ & $6.04 \pm 0.46^{*}$ & $17.73 \pm 2.30^{* *}$ & $5.00 \pm 1.35^{* *}$ \\
\hline
\end{tabular}

Note: ${ }^{\star}$ Significantly different to control values at $P<0.05$ or $P<0.01\left({ }^{* *}\right)$.

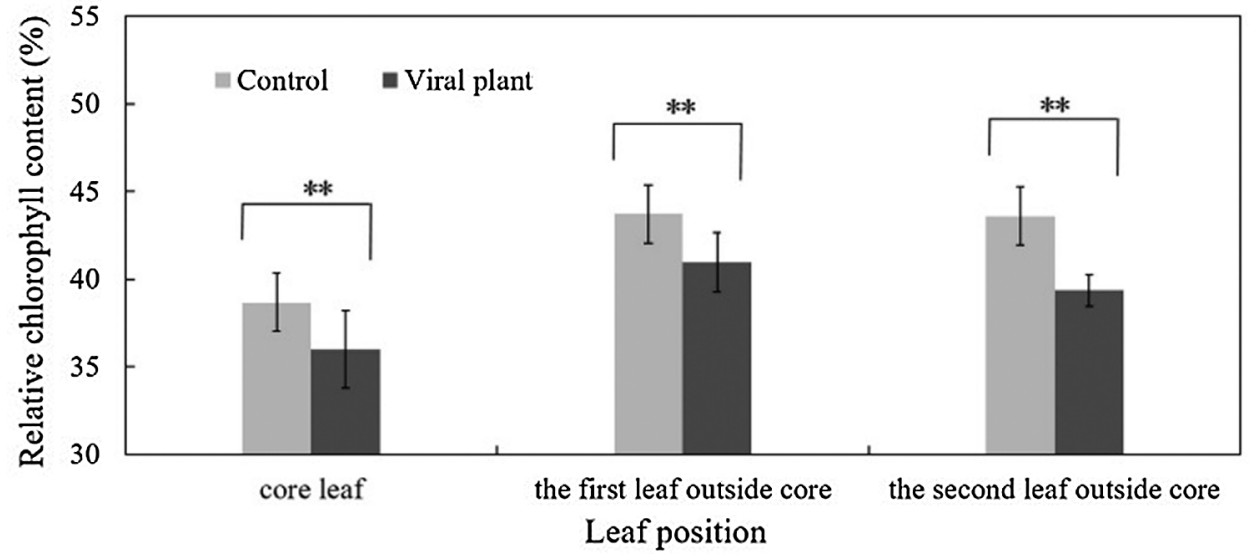

TABLE 3
FIGURE 3. The effect of SVBV and $\mathrm{SMoV}$ infection on the relative chlorophyll content of leaves of 'Benihope' strawberry. The vertical bar indicates the SD; $\mathrm{N}=3$ replicates (15 plants per replicate). Statistically significant different between viral plants (VIS) and control plants are shown by asterisks: ${ }^{* *} P<0.01$.

The effect of SVBV and SMoV on chlorophyll and carotene content in leaves of 'Benihope' strawberry

\begin{tabular}{llllll}
\hline & $\begin{array}{l}\text { Chlorophyll } \boldsymbol{a} \\
(\mathbf{m g} / \mathbf{g} \text { FW })\end{array}$ & $\begin{array}{l}\text { Chlorophyll } \boldsymbol{b} \\
(\mathbf{m g} / \mathbf{g} \text { FW })\end{array}$ & $\begin{array}{l}\text { Carotene } \\
(\mathbf{m g} / \mathbf{g} \text { FW })\end{array}$ & $\begin{array}{l}\text { Total chlorophyll } \\
(\mathbf{m g} / \mathbf{g} \text { FW })\end{array}$ & $\begin{array}{l}\text { Chlorophyll } \\
\boldsymbol{a} / \boldsymbol{b}\end{array}$ \\
\hline Control & $1.26 \pm 0.06$ & $0.67 \pm 0.04$ & $0.32 \pm 0.01$ & $1.95 \pm 0.08$ & $1.87 \pm 0.07$ \\
VIS & $1.24 \pm 0.06$ & $0.63 \pm 0.04^{\star}$ & $0.33 \pm 0.01$ & $1.86 \pm 0.09^{\star}$ & $1.97 \pm 0.14$ \\
\hline
\end{tabular}

Note: ${ }^{*}$ Significantly different to control values at $P<0.05$.

TABLE 4

The effect of SVBV and SMoV on photosynthetic parameters in leaves of 'Benihope' strawberry

\begin{tabular}{lllll}
\hline & $\begin{array}{l}\mathbf{P}_{\mathbf{N}} \\
\left(\mu \mathbf{m o l} / \mathbf{m}^{2} \mathbf{s}\right)\end{array}$ & $\begin{array}{l}\mathbf{g}_{\mathbf{s}} \\
\left(\mathbf{m o l} / \mathbf{m}^{2} \mathbf{s}\right)\end{array}$ & $\begin{array}{l}\mathbf{c}_{\mathbf{i}} \\
(\mu \mathbf{m o l} / \mathbf{m o l})\end{array}$ & $\begin{array}{l}\mathbf{E} \\
\left(\mathbf{m m o l} / \mathbf{m}^{2} \mathbf{s}\right)\end{array}$ \\
\hline Control & $10.01 \pm 1.12$ & $0.31 \pm 0.04$ & $301.00 \pm 11.50$ & $3.35 \pm 0.29$ \\
VIS & $8.78 \pm 0.92^{\star *}$ & $0.19 \pm 0.05^{* *}$ & $288.50 \pm 14.45^{\star}$ & $2.70 \pm 0.46^{* *}$ \\
\hline
\end{tabular}

Note: ${ }^{*}$ Significantly different to control values at $P<0.05$ or $P<0.01\left({ }^{* *}\right)$. 


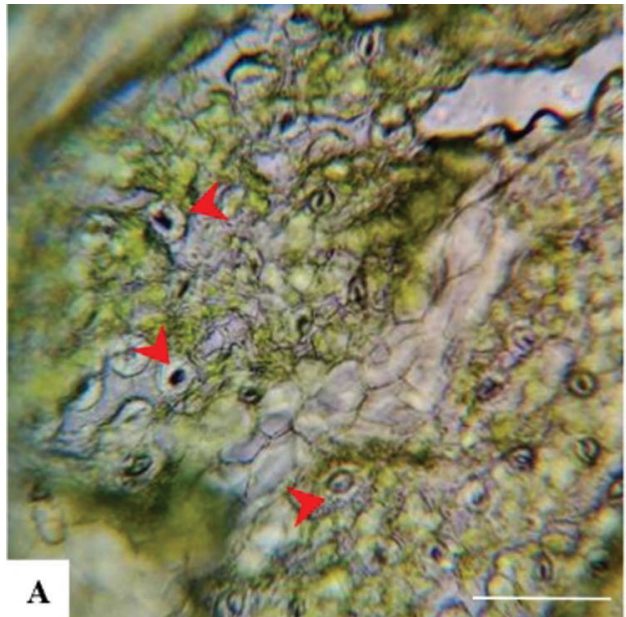

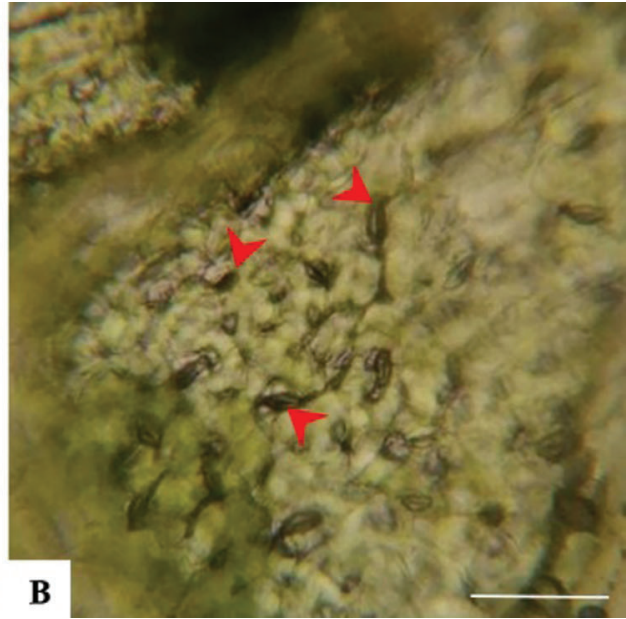

FIGURE 4. Stomata on 'Benihope' strawberry leaves. (A) The stomatal aperture of control leaves; (B) The stomatal aperture of VIS leaves. Scale bar $=25 \mu \mathrm{m}$.

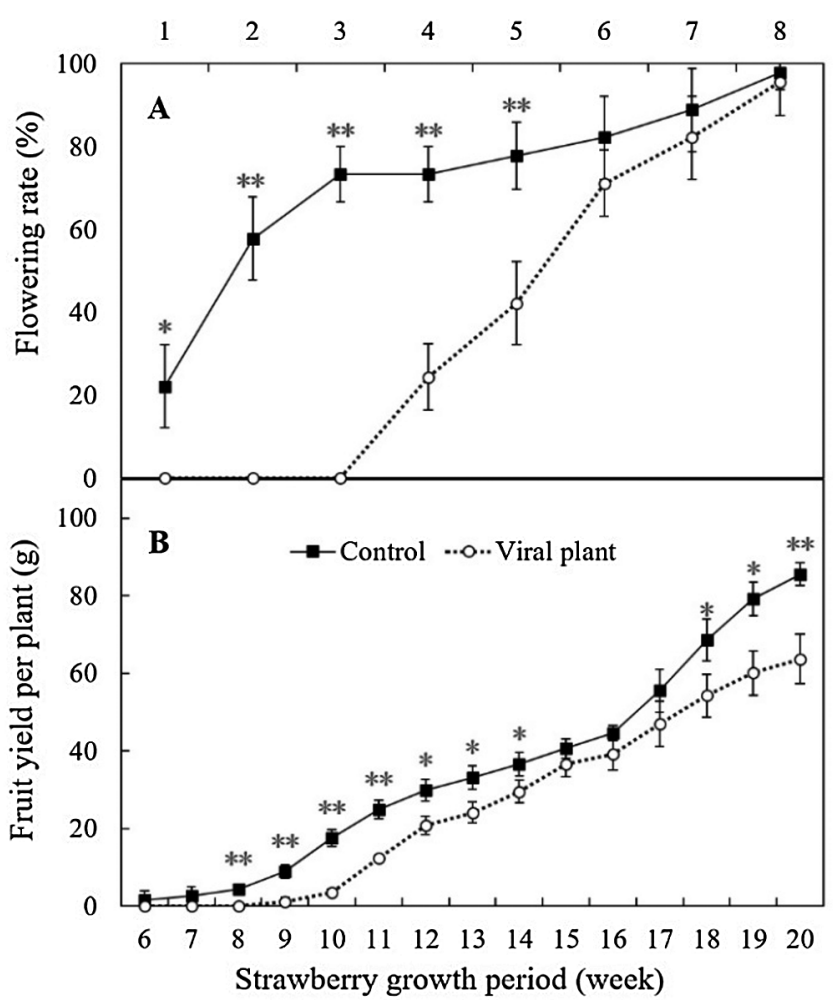

FIGURE 5. The effect of SVBV and SMoV infection on the flowering rate (A) and fruit yield per plant (B) of 'Benihope' strawberry. The vertical bar indicates the $\mathrm{SD} ; \mathrm{N}=3$ replicates (15 plants per replicate). Statistically significant different between viral plants (VIS) and control plants are shown by asterisks: ${ }^{\star} P<0.05,{ }^{* *} P<0.01$.

10 December and produced approximately $1.1 \mathrm{~g}$ per plant on December 12 (9 weeks). The VIS fruits ripened three weeks later than the control fruits. From eight weeks to 14 weeks, the fruit yield per VIS plant was significantly lower than that per control plant. At 20 weeks (February 27, 2019), the total fruit yield per VIS plant $(63.7 \mathrm{~g})$ was significantly lower than that per control plant (85.5 g) and both VIS and control plants finished fruiting at 20 weeks (Fig. 5B).

The parameters of strawberry fruit quality, i.e., vertical diameter, horizontal diameter and shape index did not differ significantly different between VIS and control plants. The firmness of VIS fruits was $27.54 \%$ higher than that of control plants, but the TSS and TA contents were $21.09 \%$ and $36.11 \%$ significantly lower, respectively, than those of the controls. The solid acid ratio of VIS was significantly higher (23.48\%) than that of the control (Tab. 5).

No blue spots were observed on NBT-stained leaves of control plants (Fig. 6A); however, blue spots distributed near leaf veins, indicating the accumulation of reactive $\mathrm{O}_{2}{ }^{-}$ species on VIS NBT-stained leaves (Fig. 6B). The DABstaining of leaves of control (Fig. 6C) and VIS (Fig. 6D) plants was light brown, but a yellowish-brown precipitate was observed along the veins of the VIS DAB-stained leaves, indicating the accumulation of $\mathrm{H}_{2} \mathrm{O}_{2}$ (Fig. 6D).

Following trypan blue staining, blue regions were visualized at the margins of control leaves (Fig. 6E), suggesting that dead cells were distributed on the control leaf margins. By contrast, blue regions were observed along the veins of VIS leaves (Fig. 6F), indicating the presence of dead cells. Under $40 \times$ magnification, no blue cells (dead cells) were observed near the veins of control leaves (Fig. 6G) but lots of dead cells were distributed along the veins of VIS leaves (Fig. 6H).

The CAT activity of VIS leaves was $39.93 \%$ higher than that in control leaves, which was a significant increase (Fig. 7A). The SOD activity (Fig. 7B) and proline content (Fig. 7C) did not differ significantly between control and VIS leaves. Anthocyanin content was significantly higher (50.93\%) in control leaves than in VIS leaves (Fig. 7D) and the ABA content was significantly higher (10.86\%) in VIS leaves than in control leaves (Fig. 7E).

\section{Discussion}

The production of strawberries per unit-cultivated area has gradually increased in the last decade, due to the protected cultivation and greenhouse production. However, vector transmission and vegetative reproduction assists the spread of viruses, which cause serious losses to strawberry production. According to previous reports, a severe SMoV strain, or with SVBV or SNSV can result in a reduction of fruit yield by up to $30 \%$, and mixed infection leads to more serious losses (Martin and Tzanetakis, 2006). Here, we observed that the fruit yield of single plants infected by SMoV and SVBV was $25.5 \%$ lower than that of control plants, which is consistent with previous observations 
TABLE 5

The effect of SVBV and SMoV on fruit quality of 'Benihope' strawberry

\begin{tabular}{|c|c|c|c|c|c|c|c|}
\hline & $\begin{array}{l}\text { Vertical } \\
\text { diameter }(\mathrm{mm})\end{array}$ & $\begin{array}{l}\text { Horizontal } \\
\text { diameter }(\mathrm{mm})\end{array}$ & Shape index & $\begin{array}{l}\text { Fruit firmness } \\
\left(\mathrm{kg} / \mathrm{cm}^{2}\right)\end{array}$ & $\begin{array}{l}\text { Total soluble } \\
\text { solids }(\%)\end{array}$ & $\begin{array}{l}\text { Titratable } \\
\text { acidity (\%) }\end{array}$ & Solid acid ratio \\
\hline Control & $39.71 \pm 2.64$ & $32.31 \pm 3.68$ & $1.22 \pm 0.07$ & $0.69 \pm 0.12$ & $10.67 \pm 1.08$ & $1.08 \pm 0.22$ & $9.88 \pm 1.68$ \\
\hline VIS & $40.10 \pm 2.81$ & $33.19 \pm 3.99$ & $1.21 \pm 0.10$ & $0.88 \pm 0.21^{\star \star}$ & $8.42 \pm 1.26^{\star *}$ & $0.69 \pm 0.14^{\star *}$ & $12.20 \pm 1.36^{\star *}$ \\
\hline
\end{tabular}

Note: ${ }^{\star \star}$ Significantly different to control values at $P<0.01$.
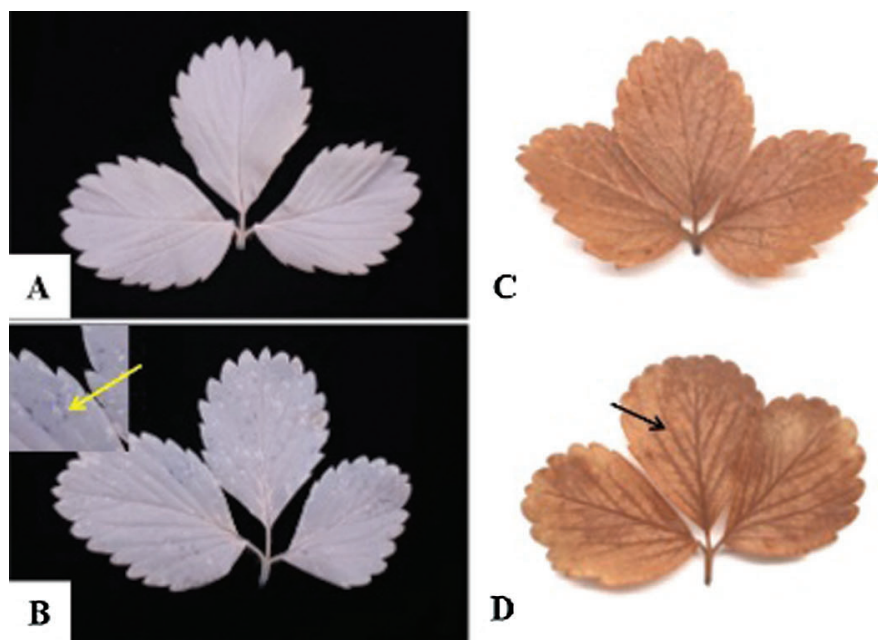

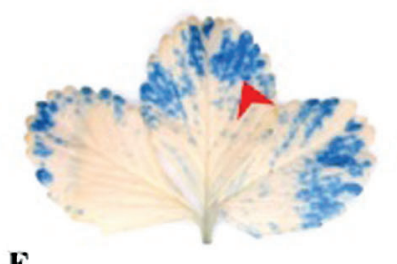

$\mathbf{E}$

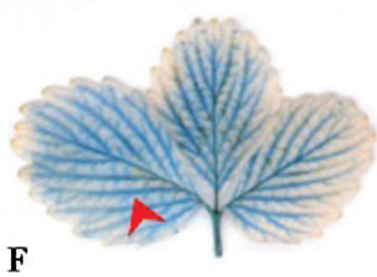

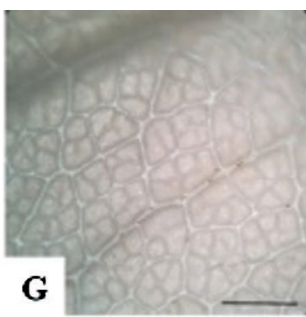

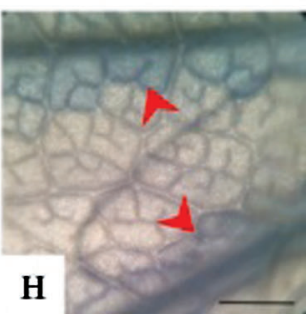

FIGURE 6. Staining of strawberry leaves. (A) Nitro-blue tetrazolium (NBT) staining of control leaves; (B) NBT staining of VIS leaves; (C) 3, 3'diaminobenzidine (DAB) staining of control leaves; (D) DAB staining of VIS leaves. (E) Trypan blue staining of control leaves; (F) Trypan blue staining of VIS leaves; (G) Trypan blue staining of cells near the veins of control leaves observed at 40× magnification with a stereomicroscope; (H) Trypan blue staining of cells near the veins of VIS leaves observed at $40 \times$ magnification with a stereomicroscope. Scale bar $=1 \mathrm{~mm}$.

(Martin and Tzanetakis, 2006; Silva-Rosales et al., 2013). We suggest that the most important reason for this was a shortening of the fruiting period. The flowering and fruit ripening time of VIS plants was delayed by about three weeks, but the end of the fruiting period was the same as that of the controls, demonstrating that the fruiting period of VIS plants was about three weeks shorter than that of the controls.

We sought potential reasons for the shortened fruiting period of the VIS plants and identified that a decrease photosynthesis was responsible. The VIS plants showed a significant reduction in $\mathrm{Chl} b$, total $\mathrm{Chl}$ and relative $\mathrm{Chl}$ content compared with control plants. This is consistent with the report that the $\mathrm{Chlb}$ content decreased in virusinfected apple leaves (Bertamini et al., 2002) and suggests that Chlb was more sensitive than Chla to similar stress conditions, as reported by Palanisamy et al. (2009) and Zhang et al. (2020). Previous research has suggested that a decrease in the Chl content of infected leaves might reduce $\mathrm{P}_{\mathrm{N}}$ (Funayama et al., 1997; Sayed, 2003). Here, we not only observed a decrease in $\mathrm{P}_{\mathrm{N}}$, but also in $\mathrm{g}_{s}, \mathrm{c}_{\mathrm{i}}$ and $\mathrm{E}$. These data are consistent with similar findings for other species following virus infection (Chia and He, 1999; Guo et al., 2005; Platt et al., 1979). Thus, another reason for the reduction in $\mathrm{P}_{\mathrm{N}}$ in VIS leaves is probably a low $\mathrm{g}_{\mathrm{s}}$ and a small stomatal aperture, as was shown by Guo et al. (2005). The reduced $c_{i}$ also reduced mesophyll conductance of $\mathrm{CO}_{2}$ and limited photosynthesis (Flexas et al., 2004; Saradadevi et al., 2017). Furthermore, the smaller leaflet area and fewer leaves in VIS plants was responsible for a decrease in photosynthesis.

Abscisic acid regulates stomatal closure by inducing $\mathrm{H}_{2} \mathrm{O}_{2}$ accumulation in response to pathogen invasion (Ton et al., 2009). Many studies have demonstrated a strong correlation between leaf $\mathrm{ABA}$ content and $\mathrm{g}_{\mathrm{s}}$ in wheat (Henson et al., 1989; Saradadevi et al., 2014; Saradadevi et al., 2015). A high degree of stomatal closure limited photosynthesis, and consequently reduced the yield of wheat (Saradadevi et al., 2017). Here, a lower $g_{s}$ and stomatal aperture in VIS leaves compared with control leaves were accompanied by a higher ABA content, and DAB staining showed a greater $\mathrm{H}_{2} \mathrm{O}_{2}$ accumulation in VIS leaves. These results indicate that $\mathrm{ABA}$ probably results in stomatal closure by exacerbating $\mathrm{H}_{2} \mathrm{O}_{2}$ release, and thus, indirectly decreasing photosynthesis and yield, concurrently, the accumulation of $\mathrm{H}_{2} \mathrm{O}_{2}$ leads to cell death. ABA also inhibits flowering (Levy and Dean, 1998). Finkelstein (2006) showed that the transcription of FLOWERING LOCUS C (FLC) was enhanced when ABA prevents FLOWERING CONTROL LOCUS A (FCA) from interacting with FLOWERING LOCUS Y (FY), which consequently causes a delay in flowering. Moreover, leaf ABA also negatively influences wheat pollination (Innes et al., 1984) and is associated with pollen sterility (Ji et al., 2011). Therefore, we speculate that the high $\mathrm{ABA}$ content observed here may play an important 


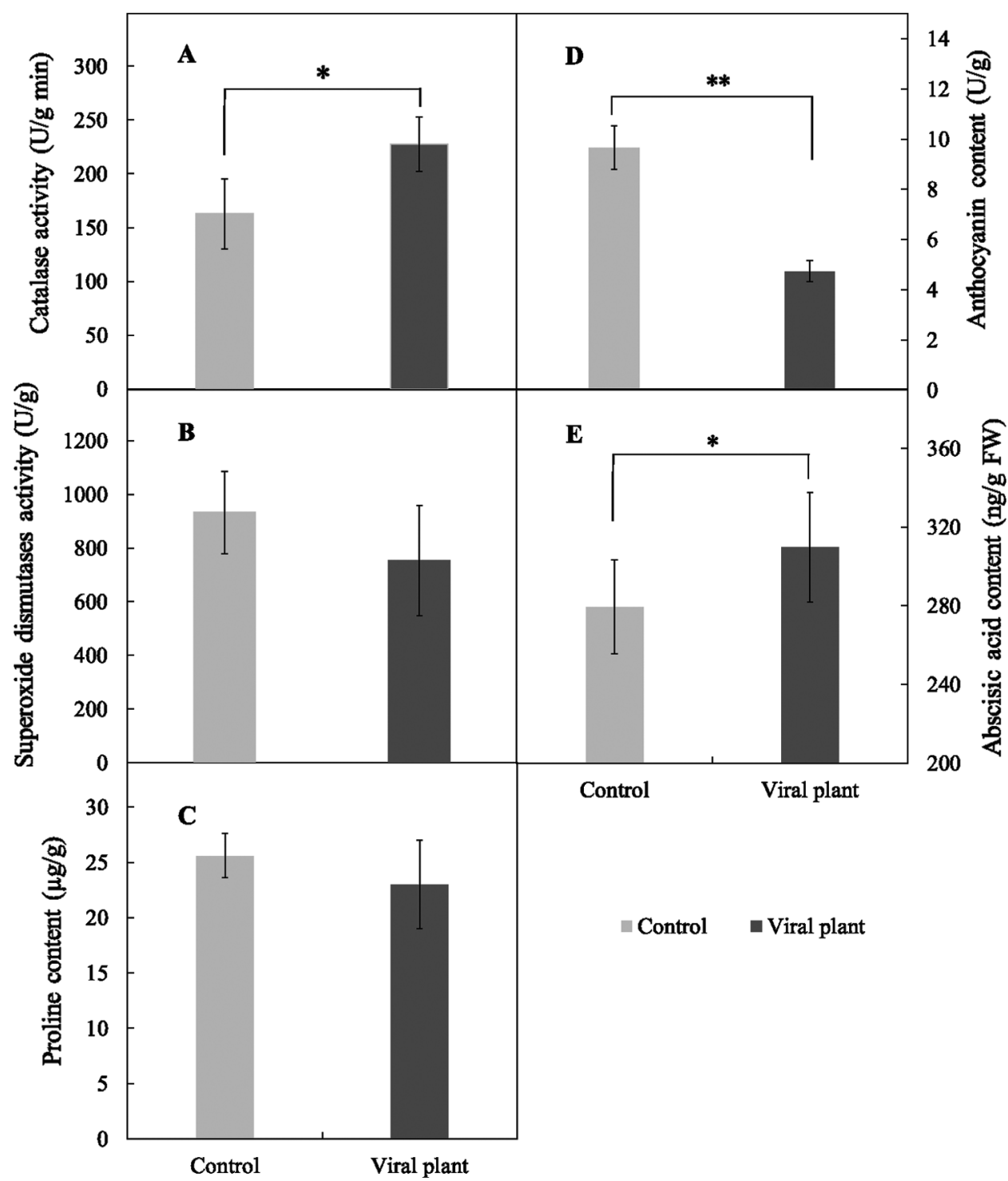

FIGURE 7. The effects of SVBV and $\mathrm{SMoV}$ infection on catalase activity (A), superoxide dismutase activity (B), proline content $(\mathrm{C})$, anthocyanin content (D) and abscisic acid content (E) of leaves of 'Benihope' strawberry. The vertical bar indicates the SD; $\mathrm{N}=3$ replicates (15 plants per replicate). Statistically significant different between viral plants (VIS) and control plants are shown by asterisks: ${ }^{\star} P<0.05,{ }^{*} P<0.01$. role in strawberry flowering, pollination and/or pollen sterility, although further study is necessary to clarify this role.

Proline is considered a physiological marker of plant stress, because it accumulates under environmental stresses (Crizel et al., 2020). Here, in contrast to data from other studies, no significant difference in proline content was observed between VIS leaves and healthy leaves. Proline also possesses an antioxidant function, similar to anthocyanins and antioxidases, which might confer plant tolerance to external stresses (Szabados and Savouré, 2010). Here, we demonstrated that $\mathrm{O}_{2}{ }^{-}, \mathrm{H}_{2} \mathrm{O}_{2}$ and dead cells accumulated along the veins of VIS leaves, indicating that $\mathrm{SMoV}$ and SVBV may trigger ROS accumulation and cause cell death in VIS plants. These results are consistent with those of Conti et al. (2012) and Yang et al. (2020), who showed that tobacco mosaic virus and chilli veinal mottle virus stimulated ROS accumulation, and infected leaves underwent cell death. Correspondingly, we observed a higher CAT activity in VIS leaves than in control leaves, suggesting that the defense response of VIS plants involves the induction of CAT to eliminate $\mathrm{H}_{2} \mathrm{O}_{2}$. This is consistent with the results of other studies that demonstrated the inhibition of cell death by CAT (Riedle-Bauer, 2000). The decrease in the activity of SOD in
VIS leaves was not significant, which contrasts with previous findings that showed a rapid increase following virus infection (Lv et al., 2020; Li et al., 2019; Lan et al., 2020). Anthocyanins in leaves possess ROS scavenging activity and function to maintain photosynthetic capacity (Xu and Rothstein, 2018). Here, the anthocyanin content in VIS leaves decreased significantly in comparison to that in control leaves, demonstrating that the photosynthetic system was impaired. SMoV and SVBV infection probably caused cell death along the leaf veins by inducing ROS accumulation, whilst concomitantly decreasing plant resistance and photosynthetic capacity by blocking anthocyanin synthesis.

We also analyzed the effect of SMoV and SVBV infection on strawberry fruits and observed a significant increase in firmness, and a reduction in TSS and TA in VIS fruits. These findings correspond well with those of Cieślińska and Rutkowski (2008), who demonstrated that ACLSV infection affected fruit firmness, TSS and TA in apple. The solid acid ratio of VIS fruits was higher than in the control and was associated with the greater decrease in the TA content than the TSS amount. This might explain why most virally infected fruits taste sweeter than healthy fruits; however, they contain fewer nutrients, including both TSS and TA. The 
fruits may be also less palatable due to sugar accumulation or acid reduction or both. No significant differences were observed in vertical diameter, horizontal diameter and shape index between control and VIS fruits, indicating that SMoV and SVBV infection does not affect the size of strawberry fruits.

In conclusion, 'Benihope' strawberry plants infected with SVBV and SMoV showed attenuated vigor and reduced fruit yield and quality. The reason for this is that infections with these viruses leads to leaf-cell death by inducing ROS accumulation, and to a decrease in photosynthesis by reducing photosynthetic parameters, chlorophyll content, stomatal aperture, and anthocyanin content. The viruses also increased the ABA content, which can inhibit flowering or affect pollination and pollen sterility. In addition, viral infection decreased strawberry flavor by enhancing fruit firmness and causing a decrease in fruit TSS and TA content. To our knowledge, this is the first detailed description of the effect of SVBV and SMoV infection on the growth and development of strawberry.

Acknowledgement: The authors are grateful to Mr Shujiang Tian at Donggang City, Liaoning Province for providing strawberry plants infected with strawberry vein banding virus and strawberry mottle virus.

Availability of Data and Materials: All data generated or analyzed during this study are included in this published article.

Author Contribution: LF: Conceptualization, Formal analysis, Data curation, Writing-original draft. DS: Investigation, Methodology, Validation, Visualization. YK: Conceptualization, Data curation, Writing-review. MW: Investigation, Visualization, Methodology. TX: Software, Methodology. XZ: Investigation, Visualization. HW: Supervision, Writing-review \& editing, Project administration, Funding acquisition.

Ethics Approval: This work did not involve any studies on human participants or animals.

Funding Statement: This study was funded by the National Key R\&D Program of China (2019YFD1001800).

Conflicts of Interest: The authors declare that they have no conflicts of interest to report regarding the present study.

\section{References}

Ábrahám E, Hourton-Cabassa C, Erdei L, Szabados L (2010). Methods for determination of proline in plants. In: Sunkar R (ed.), Plant Stress Tolerance. Methods in Molecular Biology, vol. 639, pp. 317-331. DOI 10.1007/978-1-60761-702-020.

Berezin OY, Tur'yan YI, Kuselman I, Shenhar A (1995). Alternative methods for titratable acidity determination. Talanta 42: 507-517. DOI 10.1016/0039-9140(95)01448-K.

Bertamini M, Grando MS, Muthuchelian K, Nedunchezhian N (2002). Effect of phytoplasmal infection on PS II efficiency and thylakoid membrane protein changes in field grown apple (Malus pumila) leaves. Physiological and Molecular Plant Pathology 61: 349-356. DOI 10.1006/pmpp.2003.0450.

Chen D, Ding X, Wang A, Zhang J, Wu Z (2018). First report of strawberry crinivirus 3 and strawberry crinivirus 4 on strawberry in China. New Disease Reports 37: 24. DOI 10.5197/j.2044-0588.2018.037.024.
Chen L, Shang Q, Chen X, Xing D, Yang R, Han C, Ran C, Wei Y, Zhao X, Liu Z (2014). First report on the occurrence of cucumber mosaic virus on Fragaria ananassa in China. Plant Disease 98: 1015. DOI 10.1094/PDIS-11-13-1173-PDN.

Chen J, Zhang H, Feng M, Zuo D, Hu Y, Jiang T (2016). Transcriptome analysis of woodland strawberry (Fragaria vesca) response to the infection by Strawberry vein banding virus (SVBV). Virology Journal 13: 128. DOI 10.1186/s12985-016-0584-5.

Chia TF, He J (1999). Photosynthetic capacity in Oncidium (Orchidaceae) plants after virus eradication. Environmental and Experimental Botany 42: 11-16. DOI 10.1016/S00988472(99)00010-6.

Cieślińska M, Rutkowski K (2008). Effect of Apple chlorotic leaf spot virus on yield and quality of fruits from 'Golden Delicious' and 'Sampion' apple trees. Acta Horticulturae 781: 119124. https://sci-hub.tw/10.17660/actahortic.2008.781.17.

Conti G, Rodriguez MC, Manacorda CA, Asurmendi S (2012). Transgenic expression of Tobacco mosaic virus capsid and movement proteins modulate plant basal defense and biotic stress responses in Nicotiana tabacum. Molecular PlantMicrobe Interactions 25: 1370-1384. DOI 10.1094/MPMI03-12-0075-R.

Crizel RL, Perin EC, Siebeneichler TJ, Borowski JM, Messias RS, Rombaldi CV, Galli V (2020). Abscisic acid and stress induced by salt: Effect on the phenylpropanoid, L-ascorbic acid and abscisic acid metabolism of strawberry fruits. Plant Physiology and Biochemistry 152: 211-220. DOI 10.1016/j.plaphy.2020.05.003.

Dara SK (2015). Virus decline of strawberry in California and the role of insect vectors and associated viruses. Plant Health Progress 16: 211-215. https://ucanr.edu/sites/santabarbaracountynew/files/228068.pdf.

Daudi A, O’Brien JA (2012). Detection of hydrogen peroxide by DAB staining in Arabidopsis leaves. Bio-protocol 2: e263. https:// www.ncbi.nlm.nih.gov/pmc/articles/PMC4932902/.

Deng MQ, Lei JJ (2005). China fruit records: Strawberry volume. China Forestry Publishing House 4: 33-35 (in Chinese).

Ding XL, Chen D, Du ZG, Zhang J, Wu ZJ (2019). The complete genome sequence of a novel cytorhabdovirus identifed in strawberry (Fragaria ananassa Duch.). Archives of Virology 164: 3127-3131. DOI 10.1007/s00705-019-04390-y.

Drumm H, Mohr H (1978). The mode of interaction between blue (UV) light photoreceptor and phytochrome in anthocyanin formation of the Sorghum seedling. Photochemistry and Photobiology 27: 241-248. DOI 10.1016/B978-0-08-022677-4.50025-3.

Fan LJ, He CY, Wu MM, Gao DH, Dong ZF, Hou SF, Feng ZK (2021). Incidence, genomic diversity, and evolution of strawberry mottle virus in China. BIOCELL 45: 1137-1151, https://www.techscience.com/biocell/v45n4/42373.

FAOSTAT (2018). Crop statistics. http://www.fao.org/home/en/.

Feng RW, Wei CY (2012). Antioxidative mechanisms on selenium accumulation in Pteris vittata: A potential selenium phytoremediation plant. Plant Soil and Environment 58: 105-110. http://ir.igsnrr.ac.cn/handle/311030/26940.

Finkelstein RR (2006). Studies of abscisic acid perception finally flower. Plant Cell 18: 786-791. DOI 10.1105/tpc.106.041129.

Flexas J, Bota J, Loreto F, Cornic G, Sharkey TD (2004). Diffusive and metabolic limitations to photosynthesis under drought and salinity in C3 plants. Journal of Plant Biology 6: 269-279. DOI 10.1055/s-2004-820867.

Frazier NW (1955). Strawberry vein banding virus. Phytopathology 45: $307-312$. 
Funayama S, Hikosaka K, Yahara T (1997). Effects of virus infection and growth irradiance on fitness components and photosynthetic properties of Eupatorium makinoi (Compositae). American Journal of Botany 84: 823-829. DOI 10.2307/2445818.

Guo DP, Guo YP, Zhao JP, Liu H, Peng Y, Wang QM, Chen JS, Rao GZ (2005). Photosynthetic rate and chlorophyll fluorescence in leaves of stem mustard (Brassica juncea var. tsatsai) after turnip mosaic virus infection. Plant Science 168: 57-63. DOI 10.1016/j.plantsci.2004.07.019.

He CY, Gao DH, Fan LJ, Xu TF, Xing F, Li SF, Wang HQ (2021). The occurrence of strawberry virus 1 infecting strawberry in Shandong province, China. Plant Disease, Epub ahead of print. PMID: 33736465. DOI 10.1094/PDIS-01-21-0038-PDN.

Henson IE, Jensen CR, Turner NC (1989). Leaf gas exchange and water relations of lupins and wheat. III. Abscisic acid and drought-induced stomatal closure. Functional Plant Biology 16: 429-442. DOI 10.1071/PP9890429.

Innes P, Blackwell RD, Quarrie SA (1984). Some effects of genetic variation in drought-induced abscisic acid accumulation on the yield and water use of spring wheat. Journal of Agricultural Science 102: 341-351. DOI 10.1017/S0021859600042660.

Jambunathan N (2010). Determination and detection of reactive oxygen species (ROS), lipid peroxidation, and electrolyte leakage in plants. In: Sunkar R (ed.), Plant Stress Tolerance, Methods in Molecular Biology, vol. 639, pp. 292-298. DOI 10.1007/978-1-60761-702-018.

Ji X, Dong B, Shiran B, Talbot MJ, Edlington JE, Hughes T (2011). Control of abscisic acid catabolism and abscisic acid homeostasis is important for reproductive stage stress tolerance in cereals. Plant Physiology 156: 647-662. DOI 10.1104/pp.111.176164.

Lan HH, Lai BC, Zhao P, Dong X, Wei WT, Ye YJ, Wu ZJ (2020). Cucumber mosaic virus infection modulated the phytochemical contents of Passiflora edulis. Microbial Pathogenesis 138: 103828. DOI 10.1016/j.micpath.2019.103828.

Levy YY, Dean C (1998). The transition to flowering. Plant Cell 10: 1973-1989. DOI 10.1105/tpc.10.12.1973.

Li L, Yang H (2011). First report of Strawberry necrotic shock virus in China. Plant Disease 95: 1198. DOI 10.1094/PDIS-02-11-0121.

Li L, Yang H, Zhao M, Lai Y (2014). Detection of Strawberry mottle virus by molecular hybridization. Journal of Chemical and Pharmaceutical Research 6: 426-429. https://www.jocpr. $\mathrm{com} /$ articles/detection-of-strawberry-mottle-virus-by-molecularhybridization.pdf.

Li T, Huang Y, Xu ZS, Wang F, Xiong AS (2019). Salicylic acidinduced differential resistance to the Tomato yellow leaf curl virus among resistant and susceptible tomato cultivars. BMC Plant Biology 19: 173. DOI 10.1186/s12870-019-1784-0.

Lichtenthaler HK, Buschmann C (2001). Chlorophylls and carotenoids: Measurement and characterization by UV-VIS spectroscopy. Current Protocols in Food analytical Chemistry 1: 171-178. DOI 10.1002/0471142913.faf0403s01.

Luo GJ, Xue L, Xu WJ, Zhao J, Wang J, Ding Y, Luan K, Lei JJ (2019). Breeding decaploid strawberry with improved cold resistance and fruit quality. Scientia Horticulturae 251: 1-8. DOI 10.1016/j.scienta.2019.03.001.

Luo Y, Ge C, Ling YJ, Mo F, Yang M et al. (2020). ABA and sucrose co-regulate strawberry fruit ripening and show inhibition of glycolysis. Molecular Genetics and Genomics 295: 421-438. DOI 10.1007/s00438-019-01629-w.

Lv X, Xiang SY, Wang XC, Wu L, Liu CY et al. (2020). Synthetic chloroinconazide compound exhibits highly efficient antiviral activity against tobacco mosaic virus. Pest Management Science 76: 3636-3648. DOI 10.1002/ps.5910.

Mahmoudpour A (2003). Diagnosis and quantification of Strawberry vein banding virus using molecular approaches. Scientia Horticulturae 656: 69-74. DOI 10.17660/ActaHortic.2004.656.9.

Mandadi KK, Scholthof KBG (2013). Plant immune responses against viruses: How does a virus cause disease? Plant Cell 25: 1489-1505. DOI 10.1105/tpc.113.111658.

Martin RR, Tzanetakis IE (2006). Characterization and recent advances in detection of strawberry viruses. Plant Disease 90: 384-396. DOI 10.1094/PD-90-0384.

Maule A, Leh V, Lederer C (2002). The dialogue between viruses and hosts in compatible interactions. Current Opinion in Plant Biology 5: 279-284. DOI 10.1016/s1369-5266(02)00272-8.

Mráz I, Petrzik K, Franova-Honetslegrova J, Sip M (1997). Detection of Strawberry vein banding virus by polymerase chain reaction and dot blot hybridization. Acta Virologica 41: 241-242. https://pubmed.ncbi.nlm.nih.gov/9391655/.

Palanisamy P, Michael PI, Muthuchelian K (2009). Physiological response of yellow vein mosaic virus-infected bhendi [Abelmoschus esculentus] leaves. Physiological and Molecular Plant Pathology 74: 129-133. DOI 10.1016/j.pmpp.2009.10.003.

Petrzik K, Beneš V, Mráz I, Honetšlegrová-Fránová J, Ansorge W, Špak J (1998). Strawberry vein banding virus-definitive member of the genus Caulimovirus. Virus Genes 16: $303-$ 305. DOI 10.1023/a:1008039024963.

Platt SG, Henriques F, Rand L (1979). Effects of virus infection on the chlorophyll content, photosynthetic rate and carbon metabolism of Tolmiea menziesii. Physiological Plant Pathology 15: 351-365. DOI 10.1016/0048-4059(79)90086-9.

Prentice I, Harris R (1946). Resolution of strawberry virus complexes by means of the aphis vector Capitophorus fragariae Theob. Annals of Applied Biology 33: 50-53. DOI 10.1111/j.1744-7348.1946. tb06273.x.

Riedle-Bauer M (2000). Role of reactive oxygen species and antioxidant enzymes in systemic virus infections of plants. Journal of Phytopathology 148: 297-302. DOI 10.1046/ j.1439-0434.2000.00503.x.

Sanfacon H, Dasgupta I, Fuchs M, Karasev AV, Petrzik K, Thompson JR, Tzanetakis I, Vlugt R, Wetzel T, Yoshikawa N (2020). Proposed revision of the family Secoviridae taxonomy to create three subgenera, Satsumavirus, Stramovirus and Cholivirus, in the genus Sadwavirus. Archives of Virology 165: 527-533. DOI 10.1007/s00705-019-04468-7.

Saradadevi R, Bramley H, Siddique KHM, Edwards E, Palta JA (2014). Contrasting stomatal regulation and leaf $\mathrm{ABA}$ concentrations in wheat genotypes when split root systems were exposed to terminal drought. Field Crops Research 162: 77-86. DOI 10.1016/j.fcr.2014.02.004.

Saradadevi R, Bramley H, Palta JA, Edwards E, Siddique KHM (2015). Root biomass in the upper layer of the soil profile is related to the stomatal response of wheat as the soil dries. Functional Plant Biology 43: 62-74. DOI 10.1071/FP15216.

Saradadevi R, Palta JA, Siddique KH (2017). ABA-mediated stomatal response in regulating water use during the development of terminal drought in wheat. Frontiers in Plant Science 8: 1251. DOI 10.3389/fpls.2017.01251.

Sayed O (2003). Chlorophyll fluorescence as a tool in cereal crop research. Photosynthetica 41: 321-330. DOI 10.1023/B: PHOT.0000015454.36367.e2.

Silva-Rosales L, Vazquez-Sanchez M, Gallegos V, Ortiz-Castellanos M, Rivera-Bustamante R, Davalos-Gonzalez P, Jofre-Garfias 
A (2013). First report of Fragaria chiloensis cryptic virus, Fragaria chiloensis latent virus, Strawberry mild yellow edge virus, Strawberry necrotic shock virus, and Strawberry pallidosis associated virus in single and mixed infections in strawberry in Central Mexico. Plant Disease 97: 1002. DOI 10.1094/PDIS-11-12-1103-PDN.

Strober W (2015). Trypan blue exclusion test of cell viability. Current Protocols in Immunology 111: A3.B.1-A3.B.3. DOI 10.1002/ 0471142735.ima03bs111.

Szabados L, Savouré A (2010). Proline: A multifunctional amino acid. Trends in Plant Science 15: 89-97. DOI 10.1016/j. tplants.2009.11.009.

Thompson JR, Dasgupta I, Fuchs M, Iwanami T, Karasev AV et al. (2017). ICTV virus taxonomy profile: Secoviridae. Journal of General Virology 98: 529-531. DOI 10.1099/ jgv.0.000779.

Ton J, Flors V, Mauch-Mani B (2009). The multifaceted role of ABA in disease resistance. Trends in Plant Science 14: 310-317. DOI 10.1016/j.tplants.2009.03.006.

Tzanetakis IE (2010). Emerging strawberry virus and virus-like diseases in the world. Julius-Kühn-Archiv 28: 41-43. https://ojs.openagrar.de/index.php/JKA/article/view/402/0.
Tzanetakis IE, Martin RR (2013). Expanding field of strawberry viruses which are important in North America. International Journal of Fruit Science 13: 184-195. https://www.ars.usda.gov/ ARSUserFiles/3602/manuscripts/2013/2013\%20\%20Intl\%20J \%20Fruit\%20Sci\%2013\%20184-195.pdf.

Wu B, Feng J, Zhang M, Jiang S, Wang S, Xin Z, Xin X (2019). First report of Hop Stunt Viroid infecting strawberry in China. Plant Disease 103: 168-168. DOI 10.1094/PDIS-01-18-0164-PDN.

$\mathrm{Xu} \mathrm{ZH}$, Rothstein SJ (2018). ROS-Induced anthocyanin production provides feedback protection by scavenging ROS and maintaining photosynthetic capacity in Arabidopsis. Plant Signaling and Behavior 13: e1451708. DOI 10.1080/ 15592324.2018.1451708.

Yang T, Qiu L, Huang WY, Xu QY, Zou JL, Peng QD, Lin HH, Xi DH (2020). Chilli veinal mottle virus HCPro interacts with catalase to facilitate virus infection in Nicotiana tabacum. Journal of Experimental Botany 71: 5656-5668. DOI 10.1093/jxb/eraa304.

Zhang WJ, Zhang XJ, Lang DY, Li M, Liu H, Zhang XH (2020). Silicon alleviates salt and drought stress of Glycyrrhiza uralensis plants by improving photosynthesis and water status. Biologia Plantarum 64: 302-313. https://bp.ueb.cas. cz/pdfs/bpl/2020/01/56.pdf. 